\title{
Action of vitamin $E$ on experimental severe acute liver failure
}

\author{
Fabiano Moraes MIGUEL1,5, Elizângela Gonçalves SCHEMITT2,5,6, Josieli Raskopf COLARES2,5,6, \\ Renata Minuzzo HARTMANN2,5,6, Maria Isabel MORGAN-MARTINS 4 and Norma Possa MARRON|1,2,3,5,6
}

Received 15/8/2016 Accepted 28/11/2016

ABSTRACT - Background - Severe Acute Liver Failure (ALF) is a life-threatening clinical syndrome characterized by hepatocyte necrosis, loss of hepatic architecture, and impairment of liver functions. One of the main causes of ALF is hepatotoxicity from chemical agents, which damage hepatocytes and result in increase of reactive oxygen species. The vitamin E isoform is the one with the strongest biological antioxidant activity. Objective - To evaluate the antioxidant effect of vitamin E in this ALF model. Methods - We used 56 rats (mean weight of $300 \mathrm{~g}$ ) divided into eight groups, four groups assessed at 24 hours and 4 assessed at 48 hours after induction: control group (CO); Vitamin E (Vit. E); Thioacetamide (TAA) and Thioacetamide + Vitamina E (TAA+Vit.E). Rats were submitted to injections of thioacetamide ( $400 \mathrm{mg} / \mathrm{kg}$ i.p.) at baseline and 8 hours later. Vitamin E (100 $\mathrm{mg} / \mathrm{kg}$ ip) was administered 30 minutes after the second dose of thioacetamide. The 48-hour group rats received two additional doses of vitamin $\mathrm{E}$ (24h and 36h). At $24 \mathrm{~h}$ or 48 hours after the administration of the first dose of TAA, rats were weighed and anesthetized and their blood sampled for evaluation of liver integrity through enzymes aspartate aminotransferase (AST) and alanine aminotransferase (ALT). Liver tissue was sampled for assessment of lipid peroxidation (LPO) by the technique TBARS, antioxidant enzymes SOD, CAT, GPx and GST activity, levels of the $\mathrm{NO}_{2} / \mathrm{NO}_{3}$ and histology by H\&E in two times. The results were expressed as mean \pm standard deviation and statistically analyzed by ANOVA followed by Student-Newman-Keuls, with $P<0.05$ considered as significant. Results - After treatment with vitamin E, we observed a reduction in liver enzymes AST (U/L) (101.32 \pm 19.45 in 24 hours and $97.85 \pm 29.65$ in 48 hours) related to the TAA group (469.56 \pm 0.69 in 24 hours and $598.23 \pm 55.45$ in 48 hours) and ALT (U/L) ( $76.59 \pm 8.56$ in 24 hours and $68.47 \pm 6.49$ in 48 hours) compared to the TAA group (312.21 \pm 10.23 in 24 hours and $359.15 \pm 17.58$ in 48 hours). There was a reduction of LPO (nmol/mg Prot) in the TAA+Vit.E group ( $0.77 \pm 0.07$ in 24 hours and $0.95 \pm 0.08$ in 48 hours) compared to the TAA group ( $1.50 \pm 0.07$ in 24 hours e $1.65 \pm 0.16$ in 48 hours). SOD decreased in the TAA+Vit.E group ( $49.48 \pm 9.47$ in 24 hours and $62.45 \pm 18,47$ in 48 hours), related to the TAA group ( $98.46 \pm 15.48$ in 24 hours and $154.13 \pm 21.46$ in 48 hours), as well as GST (nmol/min/mg Prot) in the TAA+Vit.E group ( $350.57 \pm 36.93$ in 24 hours and $453.29 \pm 13.84$ in 48 hours) compared to the TAA group ( $561.57 \pm 64.56$ in 24 hours and $673.43 \pm 38.13$ in 48 hours). There was an increase in CAT ( $\mathrm{pmol} / \mathrm{min} / \mathrm{mg}$ Prot) in the TAA+Vit.E group ( $3.40 \pm 0.44$ in 24 hours and $3.0 \pm 0.35$ in 48 hours) compared to the TAA group (1.65 \pm 0.21 in 24 hours and $1.86 \pm 0.42$ in 48 hours). The GPx (nmol/min $/ \mathrm{mg}$ Prot) increased in 24 hours in the TAA+Vit.E group (1.01 \pm 0.16 ) compared to the TAA group $(0.41 \pm 0.04)$ and decreased in 48 hours $(1.19 \pm 0.17)$ compared to the TAA group $(1.76 \pm 0.21)$. There was a reduction in $\mathrm{NO} 2 / \mathrm{NO} 3(\mathrm{mmol} / \mathrm{L})$ levels in the TAA+Vit.E group (31.47 \pm 4.26 in 24 hours and $38.93 \pm 5.20$ in 48 hours) compared to the TAA group (49.37 \pm 5.12 in 24 hours and $53.53 \pm 5.97$ in 48 hours). The histopathological evaluation showed a decrease in liver injury (necrosis and inflammation) in both studied times. Conclusion - These results suggest that vitamin E was able to protect the liver from lesions caused by thioacetamide.

HEADINGS - Acute liver failure. Thioacetamide. Oxidative stress. Antioxidants.

\section{INTRODUCTION}

Severe Acute Liver Failure (SALF) is a syndrome with high morbidity and mortality rates and low prevalence. It is characterized by sudden onset in patients with previously normal liver with rapid progress, leading to hepatocellular insufficiency, which translates into extensive metabolic disturbances, particular susceptibility to bacterial or fungal infections, collapse of multiple organs, coagulopathy, and central nervous system disorders, with mortality reaching $80 \%(6,24,27)$. The severe acute attack on the hepatic parenchyma can have different etiologies, such as drugs, xenobiotics and viruses. At present, the treatment of excellence in most cases is liver transplantation. The availability of organs is limited, however, precluding the use of such therapy in all necessary cases. Furthermore, few are the hospitals that have competent surgical teams to effectively perform liver transplantation. The acknowledged therapeutic effectiveness of $\mathrm{N}$-acetylcysteine in cases of SALF triggered by intake of large doses of paracetamol gives us an indication of the possible therapeutic application of other compounds that can act in such situations. So, attentions have been focused on the possibility of restoring liver mass and function through various treatments, in an attempt to delay or arrest the progress of the disease $(18,24,28,29,31)$.

Research on experimental models of ALT play an extremely important role for the study of its pathogenesis and the many stages

Declared conflict of interest of all authors: none

Disclosure of funding: no funding received

1 Programa de Pós-Graduação BioSaúde, Universidade Luterana do Brasil, Canoas, RS, Brasil; 2 Programa de Pós-Graduação em Medicina: Ciências Médicas, Universidade Federal do Rio Grande do Sul, Porto Alegre, RS, Brasil; 3 Programa de Pós-Graduação em Ciências Biológicas: Fisiologia - Universidade Federal do Rio Grande do Sul, Porto Alegre, RS, Brasil; 4 Programa de Pós-Graduação Pró-Saúde, Universidade Luterana do Brasil, Canoas, RS, Brasil; ${ }^{5}$ Laboratório de Estresse Oxidativo e Antioxidantes, Universidade Luterana do Brasil, Canoas, RS, Brasil; ${ }_{6}^{6}$ Laboratório de Hepatologia e Gastroenterologia Experimental, Hospital de Clínicas de Porto Alegre, RS, Brasil.

Correspondence: Norma Possa Marroni. Rua José Kanan Aranha, 102. Bairro Ipanema - CEP: 91760-170 - Porto Alegre, RS, Brasil. E-mail: nmarroni@terra.com.br 
of its course. Thioacetamide (TAA) is a xenobiotic known as a potent hepatotoxic, carcinogenic and cirrhosis-inducing agent in rats $^{(5,12)}$. Its administration causes the death of hepatic cells by both centrilobular necrosis and apoptosis $(10,14,20)$. This process involves reactive oxygen species (ROS), which leads to oxidative stress (OS), with increased damage to DNA, proteins and lipids from the excessive generation of free radicals (FR) ${ }^{(15,29)}$.

Both ROS and reactive nitrogen species (RNS) as well as other free radicals are critical intermediaries in the physiopathogenesis and physiopathology of hepatocyte lesion ${ }^{(9)}$. Bioactive products resulting from lipoperoxidation are highly implicated as being key abnormalities responsible for the hepatic injury(11).

The organism relies on an antioxidant defense system against ROS and RNS, which is divided in two main types: enzymatic, such as enzymes superoxide dismutase (SOD), glutathione peroxidase (GPx), catalase (CAT) and glutathione S-Transferase (GST); and non-enzymatic, such as glutathione (GSH), ascorbic acid (vitamin C), flavonoids, vitamin E, among others ${ }^{(26)}$.

Vitamin $\mathrm{E}$ is a component of vegetable oils that is found in nature in four different forms: $\alpha, \beta, \gamma$, and $\delta$-tocopherol. Vitamin $\mathrm{E}$ is the main antioxidant vitamin transported in the blood flow by the lipid phase of plasma lipoprotein particles ${ }^{(16)}$.

The $\alpha$-tocopherol isoform is the one with the strongest biological antioxidant activity and is widely distributed in tissues and plasma. In the non-hydrophobic portion of a-tocopherol there is the hydroxyl radical $(\mathrm{HO})$, whose atom of hydrogen is easily removable. So, when peroxyl and/or alcoxyl radicals are generated during lipid peroxidation, they are likely to combine with fatty acids of the tail of vitamin $\mathrm{E}$, thus stopping to withdraw electrons from membrane fatty acids. Therefore, vitamin E, owing to its structural characteristics, acts as chain breaker, i.e. a scavenger of free radicals, thus precluding lipoperoxidation (LPO) ${ }^{(30)}$.

Given the physiopathogeny of severe SALF involving the formation of ROS and RNS, the hepatotoxic ability of TAA and the antioxidant effects of Vitamin E, this work was designed to investigate the action of this vitamin on SALF in rats.

\section{METHODS}

\section{Ethical considerations}

Animal handling complied with the ethical principles established by Federal Law No. 11.794, which regulates the scientific use of experimental animals in Brazil. This project was approved by the Ethical Research Committee of Universidade Luterana do Brasil (ULBRA) for Animal Use (CEUA- Protocol 2012 - 43P).

\section{Animals and research design}

Fifty-six male Wistar rats with mean weight of $300 \mathrm{~g}$ were used, divided in two experiments according to time of interest, $24 \mathrm{~h}$ and 48h (28 animals per experiment). Each experiment comprised four groups: control (CO) group, Vitamin E (Vit. E) group, Tioacetamide (TAA) group and Tioacetamide + Vitamin E (TAA+Vit. E). Each experimental group was composed of 7 animals $(n=7$ based on sampling calculation) obtained from the animal facility of ULBRA. Along the study period the animals were kept in plastic boxes lined with wood shavings on a $12 \mathrm{~h}$ light/dark cycle and room temperature between 20 and $25^{\circ} \mathrm{C}$. They had free access to food and water.

Thioacetamide (Sigma Chemical Co., St. Luis, MO, USA) was diluted in $1 \mathrm{~mL}$ of $0.9 \% \mathrm{NaCl}$ vehicle and administered with intraperitoneal injection (i.p.). Vitamin E ( $\alpha$-tocopherol), sup- plied in gelatinous capsules with oil by Importadora Química DELAWERE $^{\circledR}$, was administered at a dose of $125 \mathrm{mg} / \mathrm{kg}$ (i.p.)

\section{Experimental protocol}

The CO-24h group received three doses of $0.9 \% \mathrm{NaCl}$ vehicle, with the second dose given 8 hours after the first and the third and last dose 30 minutes after the second. Thioacetamide was administered at two doses of $400 \mathrm{mg} / \mathrm{Kg}$ (i.p.) each with an interval of 8 hours, while vitamin E was given at a dose of $125 \mathrm{mg} / \mathrm{kg}$ (i.p.) 30 minutes after the second dose of TAA. In the 48-hour experiment, two additional doses of vitamin E were administered, with the second dose given 24 hours after the start of the experiment and the third, 36 hours after it. Doses of vehicle at the same dilution $(0.9 \%$ $\mathrm{NaCl}, 1 \mathrm{~mL}$ ) were administered to the groups in both experiments in order to expose the animals to the same number of administrations. At the end of each experiment, animals were weighed and anesthetized with ketamine $95 \mathrm{mg} / \mathrm{kg}$ and xylazine hydrochloride $8 \mathrm{mg} / \mathrm{kg}$ (i.p.). Blood samples were collected from the retro-orbital plexus for hepatic integrity assays and livers were dissected out for posterior analyses. At the end of each experiment (24h and 48h), animals were killed by exsanguination under deep anesthesia.

\section{Plasma analyses}

Liver integrity was determined by evaluation of enzymes aspartate aminotransferase (AST) and alanine aminotransferase (ALT) in plasma using the commercial kit Boehriner Mannheim (Germany). AST (340 nm) and ALT (340 nm) activities were obtained by kinetic assay using the commercial liquiform kit Labtest ${ }^{\circledR}$.

\section{Liver homogenates}

Nine $\mathrm{mL}$ of phosphate buffer solution $(1.15 \% \mathrm{KCL})$ per gram of tissue (liver) and phenylmethylsulfonyl fluoride (PMSF) at a concentration of $100 \mathrm{mM}$ in isopropanol $(10 \mu \mathrm{L} / \mathrm{mL}$ of $\mathrm{KCl})$ were used. The tissue was homogenized in ULTRA-TURRAX for 40 seconds at $0-2^{\circ} \mathrm{C}$ and subsequently centrifuged for $10 \mathrm{~min}$ at 3000 $\mathrm{rpm}$ in refrigerated centrifuge. The precipitate was discarded and the supernatant removed and frozen at $-80^{\circ} \mathrm{C}$ for posterior biochemical analyses ${ }^{(19)}$.

\section{Protein}

The Bradford method (1976) was used to quantify proteins, with bovine albumin as standard (SIGMA). The samples were spectrophotometrically measured at $595 \mathrm{~nm}$, and the concentrations expressed in $\mathrm{mg} / \mathrm{mL}$ and used to calculate thiobarbituric acid reactive substances (TBARS) levels and antioxidant enzyme activity.

\section{Lipoperoxidation}

The amount of malondialdehyde generated by lipoperoxidation was measured by TBARS, a technique that measures the quantity of substances reacting with thiobarbituric acid. Tissue samples were placed in test tubes with a mixture of $10 \%$ thrichloroacetic acid (TCA) and $0.67 \%$ thiobarbituric acid (TBA). They were subsequently warmed in bath for 30 min and chilled in ice for about $5 \mathrm{~min}$. After chilling the samples, $1.5 \mathrm{~mL}$ of n-butyl alcohol was added to extract the pigment formed. After this procedure they were placed in stirrer for $45 \mathrm{sec}$ and centrifuged for $10 \mathrm{~min}$ at 3000 $\mathrm{rpm}$. Finally, the stained product, present in the upper fraction, was read spectrophotometrically at a wavelength of $535 \mathrm{~nm}$. The obtained TBARS concentration was expressed as nmol per milligram of protein ${ }^{(4)}$. 


\section{Analyses of antioxidant enzymes}

Glutathione S-transferase (GST) is based on an enzyme that catalyzes the formation of $1 \mathrm{mmol}$ of DNP-SG per minute at $30^{\circ} \mathrm{C}$ using $1 \mathrm{mM}$ of the concentration of (reduced) GSH and CDNB, detected spectrophotometrically at $340 \mathrm{~nm}$, values expressed in $\mathrm{mmol} / \mathrm{min} / \mathrm{mgprot}^{(21)}$. The analysis of superoxide dismutase (SOD) activity is defined as its ability to inhibit a detection system that reacts with $\mathrm{O}_{2}^{-}$. The technique of measuring SOD is based on the inhibition of this reaction with adrenalin, detected spectrophotometrically at $480 \mathrm{~nm}$. The data were expressed as units of SOD per milligram of protein (USOD/ mg prot.)(25). The analysis of catalase activity (CAT) is defined by the breakdown of hydrogen peroxide in water and oxygen, being directly proportional to its enzymatic activity, detected spectrophotometrically at $240 \mathrm{~nm}$. The results were expressed in $\mu$ moles per milligram of protein (mmoles of $\left.\mathrm{H}_{2} \mathrm{O}_{2}\right)^{(3)}$. Glutathione peroxidase (GPX) can be studied by measuring the rate of consumption of nicotinamide adenine dinucleotide (NADPH) in the reduction of glutathione oxidase, detected spectrophotometrically at $340 \mathrm{~nm}$ and its activity expressed in nmoles per minute per milligram of protein (nmol/ $\mathrm{min} / \mathrm{mg}$ prot) $)^{(13)}$.

\section{Evaluation of nitric oxide metabolites - nitrites e nitrates}

Nitric oxide production was measured indirectly through a colorimetric quantitative test by the Griess reaction. It is based on the enzymatic reduction of nitrates to nitrites in the presence of nitrate reductase and NADPH, and posterior reaction of the formed nitrites (or initially present in the samples) with Griess reagent (mixture of sulfanilamide and naphthyl ethylenediamine, specific for $\mathrm{NO}_{2}^{-}$). However, as the excess of NADPH used inhibits the Griess reaction, it is necessary to oxidize all of the NADPH not used in the reduction of nitrates. This is achieved by adding nitrate reductase. The reading was performed in a microplate reader at $540 \mathrm{~nm}$ and the results expressed in mmol of $\mathrm{NO}_{2} / \mathrm{NO}_{3}$.

\section{Histological analysis}

Histological analyses were performed on liver samples preserved in $10 \%$ formaldehyde solution for $24 \mathrm{~h}$, which were then embedded in paraffin and cut in $3 \mathrm{~mm}$ slices using a rotating microtome. Histological examinations were performed using hematoxylin-eosin staining. A single pathologist, blinded to experimental protocol, analyzed all livers under a binocular Labophot NIKON microscope, at 100X magnification.

\section{Statistical analysis}

The results were expressed as mean \pm standard error for each experimental group. The software GrapPad Instat, version 3.0 was used for the statistical analysis. For symmetrical data, simple ANOVA was used to compare the differences found in each studied parameter. The complementary Student-Newman-Keuls test was used as well for multiple comparisons. The level of significance for each comparison was at least 5\% $(P<0.05)$.

\section{RESULTS}

\section{Liver integrity}

Table 1 shows the results of AST and ALT evaluation at $24 \mathrm{~h}$ and $48 \mathrm{~h}$. The TAA groups showed a significant increase $(P<0.001)$ as compared to the $\mathrm{CO}$ group at both times, while the TAA groups receiving Vit. E $(125 \mathrm{mg} / \mathrm{kg})$ reduced these enzymes significantly
$(P<0.001)$ at both these times, decreasing and protecting from the damage triggered by TAA. It was thus demonstrated that Vit. E doses contributed to a protective effect on the liver tissue.

TABLE 1. Evaluation of enzymes AST and ALT (U/L) in the different experimental groups at the two studied times ( $24 \mathrm{~h}$ and $48 \mathrm{~h}$ )

\begin{tabular}{lcccc}
\hline Grupos & CO & VIT. E & TAA & TAA + Vit. E \\
\hline $24 \mathrm{~h}$ & & & & \\
AST & $39.05 \pm 6.55$ & $39.99 \pm 5.23$ & $469.56 \pm 0.69^{\mathrm{a}}$ & $101.32 \pm 19.45^{\mathrm{b}}$ \\
ALT & $22.36 \pm 3.45$ & $21.56 \pm 2.64$ & $312.21 \pm 10.23^{\mathrm{a}}$ & $76.59 \pm 8.56^{\mathrm{b}}$ \\
$48 \mathrm{~h}$ & & & & \\
AST & $43.12 \pm 5.63$ & $41.56 \pm 3.45$ & $598.23 \pm 55.45^{\mathrm{a}}$ & $97.85 \pm 29.65^{\mathrm{b}}$ \\
ALT & $29.48 \pm 3.12$ & $32.45 \pm 3.05$ & $359.15 \pm 17.58^{\mathrm{a}}$ & $68.47 \pm 6.49^{\mathrm{b}}$ \\
\hline
\end{tabular}

CO: control group, Vit. E: Vitamin E group; TAA: Thiocetamide group; TAA+Vit.E: Thiocetamide with Vit. E group). Data are expressed as mean \pm standard error of mean. $n=7$ per group, where $\mathbf{a}=$ significant increase $(P<0.01)$ of TAA vs Controls, and $\mathbf{b}=$ indicates significant decrease $(P<0.001)$ of TAA+Vit.E vs TAA

\section{Lipoperoxidation measurement}

LPO results for the $24 \mathrm{~h}$ and $48 \mathrm{~h}$ groups can be seen in Figure 1, where a significant increase $(P<0.001)$ of LPO was found in TAA groups as compared to the others. As Vit. E is administered at $24 \mathrm{~h}$, LPO is reduced as compared to the TAA group $(P<0.001)$, and the same was found at $48 \mathrm{~h}$. This is clear evidence that Vit. E administration in the TAA group reduces LPO at both studied times.

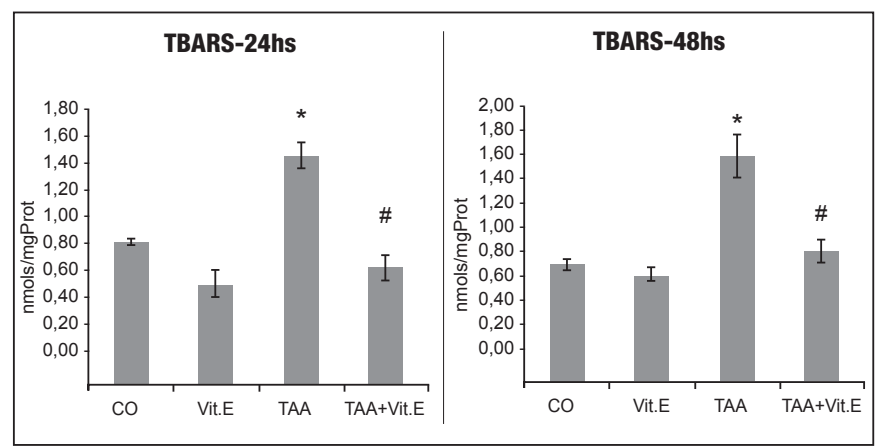

FIGURE 1. Evaluation of lipoperoxidation through TBARS (nmol/ $\mathrm{mg}$ prot) in the different experimental groups assessed at $24 \mathrm{~h}$ and $48 \mathrm{~h}$. CO: control group, Vit. E: Vitamin E group; TAA: Thiocetamide group; TAA+Vit.E: Thiocetamide with Vit. E group. Data are expressed as mean \pm standard error of mean. $n=7$ per group. * Significant increase $(P<0.05)$ of TAA vs Controls and \#significant decrease $(P<0.05)$ of TAA+Vit.E vs TAA.

\section{Antioxidant enzymes}

SOD, CAT, GPx and GST activities were assessed at $24 \mathrm{~h}$ and 48h (Table 2). GST and SOD activities were significantly increased in the TAA groups as compared to control groups at $24 \mathrm{~h}$ and $48 \mathrm{~h}$, and decreased in the TAA+Vit.E groups as compared to the TAA groups at both times. Cat activity was significantly reduced in the TAA groups as compared to controls at $24 \mathrm{~h}$ and $48 \mathrm{~h}$, and increased in the TAA+Vit.E groups as compared to TAA at both studied times. GPx showed a different pattern across the studied times. At 24h GPx activity was reduced in the TAA as compared to controls and the TAA+Vit.E group had increased GPx activity as compared to the TAA group. At 48h, GPx activity was increased in the TAA group as compared to controls and was reduced in the TAA+Vit.E group as compared to TAA. 
TABLE 2. Evaluation of antioxidant enzymes SOD, CAT, GPX and GST activities in the different studied groups and two studied times: $24 \mathrm{~h}$ and $48 \mathrm{~h}$

\begin{tabular}{|c|c|c|c|c|}
\hline Groups & $\begin{array}{c}\text { SOD } \\
\text { (USOD/min/mg Prot) }\end{array}$ & $\begin{array}{c}\text { CAT } \\
\text { (pmol/min/mg Prot })\end{array}$ & $\begin{array}{c}\text { GPX } \\
(\mathrm{nmol} / \mathrm{min} / \mathrm{mg} \text { Prot })\end{array}$ & $\begin{array}{c}\text { GST } \\
\text { (nmol/min/mg Prot) }\end{array}$ \\
\hline \multicolumn{5}{|l|}{$24 \mathrm{~h}$} \\
\hline $\mathrm{CO}$ & $36.47 \pm 7.49$ & $3.43 \pm 0.68$ & $0.76 \pm 0.09$ & $246 \pm 11.41$ \\
\hline TAA & $98.46 \pm 15.48^{\mathrm{a}}$ & $1.65 \pm 0.21^{\mathrm{c}}$ & $0.41 \pm 0.04^{c}$ & $561.57 \pm 64.56^{a}$ \\
\hline TAA + Vit. E & $49.48 \pm 9.47$ & $3.40 \pm 0.44^{\mathrm{d}}$ & $1.01 \pm 016^{\mathrm{b}}$ & $350.57 \pm 36.93^{b}$ \\
\hline \multicolumn{5}{|l|}{$48 \mathrm{~h}$} \\
\hline Vit. E & $12.96 \pm 6.48$ & $3.45 \pm 0.24$ & $0.71 \pm 0.07$ & $299.57 \pm 11.81$ \\
\hline TAA & $154.13 \pm 21.46^{a}$ & $1.86 \pm 0.42^{\mathrm{a}}$ & $1.76 \pm 0.21^{\mathrm{a}}$ & $673.43 \pm 38.13^{a}$ \\
\hline TAA + Vit. E & $62.45 \pm 18.47^{b}$ & $3.015 \pm 0.35^{\mathrm{b}}$ & $1.19 \pm 0.17^{b}$ & $453.29 \pm 13.84^{\mathrm{b}}$ \\
\hline
\end{tabular}

CO: control group, Vit. E: Vitamin E group; TAA: Thiocetamide group; TAA+Vit.E: Thiocetamide with Vit. E group. Data are expressed as mean \pm standard error of mean. $\mathrm{n}=7$ per group. $\mathrm{a}=$ significant increase $(P<0.001)$ TAA vs Controls; $\mathrm{b}=$ significant decrease $(P<0.001)$ of TAA + Vit.E vs TAA; $\mathrm{c}=$ significant increase $(P<0.05)$ of TAA vs Control groups, and $\mathrm{d}=$ significant decrease $(P<0.01) \mathrm{TAA}+$ Vit.E vs TAA

\section{Nitrites e Nitrates}

Figure 2 shows that nitric oxide metabolites increased significantly $(P<0.001)$ in the TAA groups at both times and were significantly reduced in the Vitamin E-supplemented groups $(P<0.001)$ at both studied times.

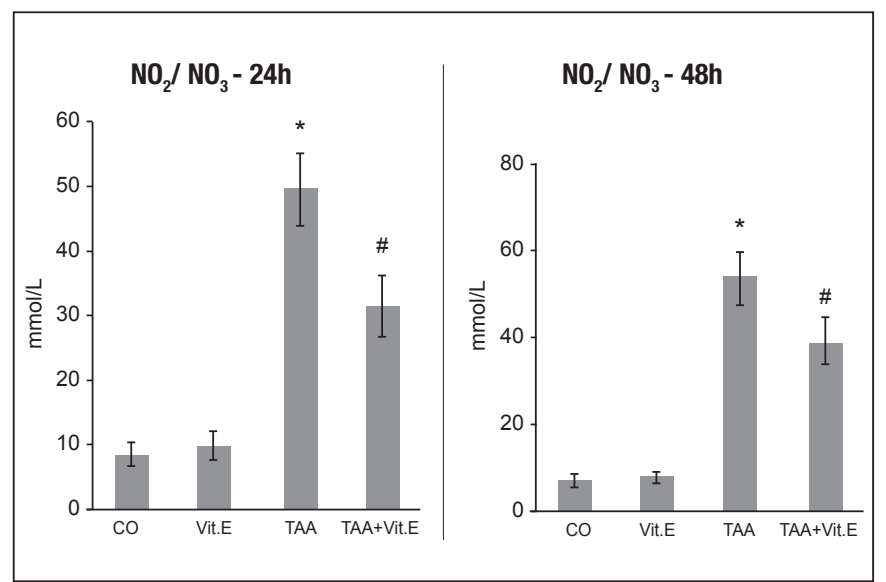

FIGURE 2. Evaluation of nitric oxide metabolites - nitrites and nitrates $(\mathrm{mmol} / \mathrm{L})$ in the different experimental groups at $24 \mathrm{~h}$ and $48 \mathrm{~h}$. CO: control group, Vit. E: Vitamin E group; TAA: Thiocetamide group; TAA+Vit.E: Thiocetamide with Vit. E group. Data are expressed as mean \pm standard error of mean. $\mathrm{n}=7$ per group. $\mathrm{a}=$ significant increase $(P<0.001)$ TAA vs Controls; $\mathrm{b}=$ significant decrease $(P<0.001)$ of TAA + Vit.E vs TAA.

\section{Histology}

Histological evaluation of liver tissue was performed by hematoxylin \& eosin (HE) staining at 200x magnification. As can be seen in Figures 3A and B (24h) and 4-A and B (48h), the CO and Vit.E groups showed normal hepatic parenchyma, with clear-cut hepatocyte cordons with well-preserved cytoplasms and nuclei. In the histology of the TAA group, shown in Figures 3C (24h) and $4 \mathrm{C}(48 \mathrm{~h})$, there is evidence of hepatocyte cordon disorganization, inflammatory infiltrate, and necrosis. In the TAA+Vit.E group, seen in Figures 3D (24h) and 4D (48h), note the preservation of hepatocyte cordons and decreased incidence of necrosis and inflammatory infiltrate in response to Vitamin E.
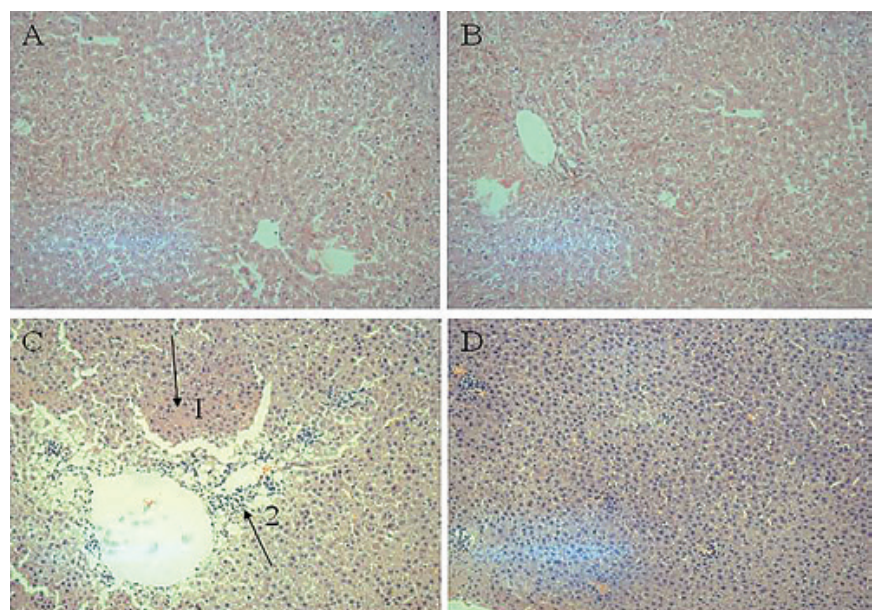

FIGURE 3. Photomicrograph of hepatic tissue by hematoxylin \& eosin (HE) stain in the different experimental groups at 24h. Magnification: 200X. $\mathrm{A}=\mathrm{CO}$ group, $\mathrm{B}=$ Vit. E group, $\mathrm{C}=$ TAA group and $\mathrm{D}=$ TAA+Vit.E group. Arrow 1: Necrosis. Arrow 2: Inflammatory infiltrate.
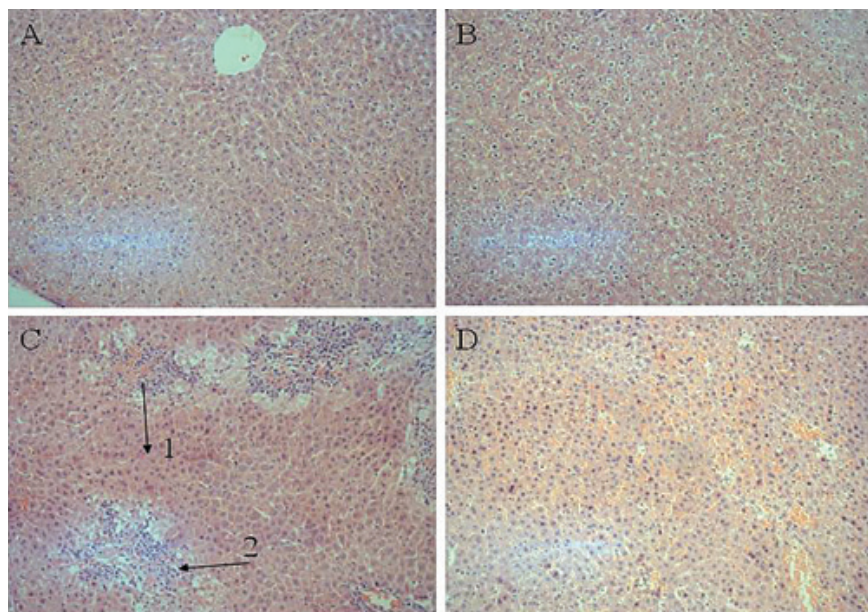

FIGURE 4. Photomicrograph of hepatic tissue by hematoxylin \& eosin (HE) stain in the different experimental groups at $48 \mathrm{~h}$. Magnification: 200X. $A=C O$ group, $B=$ Vit. E group, $C=$ TAA group and $D=$ TAA+Vit.E group. Arrow 1: Necrosis. Arrow 2: Inflammatory infiltrate. 


\section{DISCUSSION}

Severe SALF is an acute hepatic disorder with varied, poorly known physiopathogeny and established physiopathology with variants concerning etiology. Knowledge of these mechanisms is important to determine the pathways of the lesion and any potential effects of external intervention. The utilization of experimental models and antioxidant drugs comes to contribute to its understanding. Drugs that can delay the progress of the disease or reorganize the hepatic parenchyma are potential therapeutic agents for the disease.

In the present study, vitamin $\mathrm{E}$ was found to attenuate oxidative stress and inflammation in TAA-induced SALF. Enzymes AST and ALT were increased by about $1200 \%$ in the groups receiving TAA as compared to controls at $24 \mathrm{~h}$ and $48 \mathrm{~h}$. Other authors also obtained similar results by inducing toxicity in rat livers through administration of AA doses $(350 \mathrm{mg} / \mathrm{kg})$. In Vitamin E-treated groups, there was a significant decrease of about $75 \%$ in AST and ALT as compared to TAA groups at $24 \mathrm{~h}$ and $48 h^{(7,28)}$. In another study also observed a reduction of these parameters in an experimental model of toxicity, treating with flavonoid quercitin ${ }^{(8)}$

In LPO evaluation, TBARS presented an increase of 59.5\% and $94.1 \%$ at $24 \mathrm{~h}$ and $48 \mathrm{~h}$, respectively, in the TAA group. In the Vit. E group, however, values were similar to those of the control group and significantly reduced as compared to TAA groups, with reductions of $51.3 \%$ and $42.4 \%$ at $24 \mathrm{~h}$ and $48 \mathrm{~h}$, respectively. Such reduction demonstrates decreased LPO in the hepatic tissue due to the antioxidant action of vitamin $\mathrm{E}$ administered to these animals, which can be evidenced by histology, where one notes reorganization of the hepatic tissue and reduction of the inflammatory infiltrate and necrosis $2,17,28)$

Administration of Vitamin E significantly reduced SOD activity by $49.7 \%$ at $24 \mathrm{~h}$ and $59.48 \%$ at $48 \mathrm{~h}$, suggesting decreased production of $\mathrm{O}_{2}{ }^{-}$, and consequent decreased LPO, as demonstrated by histology and TBARS levels. In a study investigating the preventive effect of quercetin in animals with TAA-induced SALF, de Oliveira et al., showed significantly increased SOD activity from the administration of the flavonoid. Other works have reported decreased SOD activity from the administration of other antioxidants ${ }^{(8,22,23)}$.

CAT activity was significantly reduced in TAA groups as compared to CO groups by $51.9 \%$ and $43.6 \%$ at $24 \mathrm{~h}$ and $48 \mathrm{~h}$, respectively. TAA acts directly on the formation of $\mathrm{O}_{2}^{--}$, which act on membrane lipids and form hydroperoxide lipids, thus accounting for reduced CAT activity. The use of Vit. E significantly restored CAT activity at $24 \mathrm{~h}$ and $48 \mathrm{~h}$, with increases of $106 \%$ and $61.8 \%$, respectively, making it similar to $\mathrm{CO}$ groups and reinforcing the antioxidant effect of Vitamin E. Another study found significant reduction of CAT activity in rats, evaluating the damage caused by oxidative stress induced by high-carbohydrate diet in a model of hepatic encephalopathy(1).

The behavior of GPx activity varied across the studied times. While in the TAA group there was a reduction of $46 \%$ in GPx activity in relation to the $\mathrm{CO}$ group at $24 \mathrm{~h}$, there was an increase of it $(158.8 \%)$ at $48 \mathrm{~h}$, possibly explained by the reestablishment of the hepatic tissue. As compared to the TAA group, GPx activity in the TAA+Vit.E group presented an increase of $146.3 \%$ at $24 \mathrm{~h}$ and a decrease of $32.3 \%$ at $48 \mathrm{~h}$, which can be explained by the decreased tissue aggression due to the protective effect of Vit. E, evidenced by lower TBARS levels and histology. The increase in GPx appears to accompany the accumulation of organic peroxides formed by LPO caused by TAA. Similar results were reported in a work using antioxidant quercetin and glutamine $\mathrm{e}^{(7,31)}$.

The high toxicity of TAA in hepatocytes triggered an increase in enzyme GST, through its detoxifying protective action, with increases of $128.2 \%$ and $111 \%$ at $24 \mathrm{~h}$ and $48 \mathrm{~h}$, respectively. In the Vitamin E-treated group, however, the reduction was of 37.5\% and $32.6 \%$ at $24 \mathrm{~h}$ e $48 \mathrm{~h}$, respectively, owing to the preservation of hepatocytes by the exogenous antioxidant, as evidenced again by decreased TBARS levels and liver histology. Our findings corroborate those of other authors who evaluated GST activity in experimental model, using TAA as hepatotoxic inducer ${ }^{(31)}$.

On histological evaluation of hepatic tissue using hematoxylin $\&$ eosin (HE) staining at a magnification of 200x, CO and Vit. E groups showed hepatic cells arranged in hepatocyte cordons around capillaries with aspects of normal distribution, and visible nuclei without inflammatory infiltrates or necrosis. On the other hand, the hepatic tissue in the TAA group displayed disorganization of hepatocytes, inflammatory infiltrates, and necrosis, which accounts for increased TBARS levels at both times. Histological evaluation of the Vit.E-treated group showed a reorganization of hepatocyte cordons and smaller incidence of inflammatory infiltrate or necrosis. These evidences coincide with significant reduction of TBARS and lower lipoperoxidation in the hepatic parenchyma at both studied times, promoted by Vitamin E antioxidant action. Another author also demonstrated Vitamin E antioxidant role when administered at $200 \mathrm{mg} / \mathrm{Kg} /$ day for 3 days ${ }^{(28)}$.

The rise of metabolites $\mathrm{NO}_{2}$ and $\mathrm{NO}_{3}$ indicates an increase in NO production, which participates closely in the inflammatory and destructive process of the hepatic tissue ${ }^{(9)}$. Animals in TAA groups presented increase of NO metabolites that associate with the superoxide anion to form peroxinitrite, which is extremely damaging to hepatocytes. This increase was of $476 \%(24 \mathrm{~h})$ and $646 \%(48 \mathrm{~h})$ in relation to control groups, while Vitamin E-supplemented groups showed a reduction of $36.2 \%(24 \mathrm{~h})$ and $29.8 \%$ (48h) as compared to groups receiving TAA, which in a way can be explained by the improvement of the hepatic parenchyma. Similar findings were reported by other authors who assessed nitric oxide levels ${ }^{(7,22)}$.

From the findings it is possible to see that the Vitamin E group at $48 \mathrm{~h}$, despite having received two additional $100 \mathrm{mg} / \mathrm{Kg}$ doses of Vitamin E, presents values that are close to those obtained at $24 \mathrm{~h}$, suggesting that the dose of $100 \mathrm{mg} / \mathrm{Kg}$ administered intraperitoneally thirty minutes after TAA administration was already sufficient to protect the liver against the oxidative stress triggered by the drug.

\section{CONCLUSION}

Oxidative stress plays a key role in the aggravation of liver injury and structural and/or functional disorders of the liver. The use of antioxidants, such as vitamin E, seems promising as an attempt to prevent the complications resulting from oxidative stress and in the continuation of the disease. In the present study, TAA administration induced liver damage in rats at both $24 \mathrm{~h}$ and $48 \mathrm{~h}$ and administration of Vitamin $\mathrm{E}$ was effective in protecting the tissue at both these times. We suggest that Vitamin E can be an effective tool in the treatment of SALF and its resulting complications. However, studies with new approaches taking in 
consideration apoptosis markers, inflammatory route, and DNA damage caused by oxidative stress will be helpful in elucidating these mechanisms.

\section{ACKNOWLEDGMENT}

Dr. Cláudio Augusto Marroni and Mariana do Couto Soares, by aid during the conduct of the study. Conselho Nacional de Desenvolvimento Científico e Tecnológico (CNPq), Coordenação de Aperfeiçoamento de Pessoal de Nível Superior (CAPES) and Fundação de Amparo à Pesquisa do Estado do Rio Grande do Sul (FAPERGS) for financial support.

\section{Authors' contributions}

Miguel FM and Schemitt EG performed all of the research work; Colares JR and Hartmann RM were in charge of the experimental model; Morgan-Martins MI and Marroni NP designed the research work and the article review.

Miguel FM, Schemitt EG, Colares JR, Hartmann RM, Morgan-Martins MI, Marroni NP. Ação da vitamina E sobre a insuficiência hepática aguda grave experimental. Arq Gastroenterol. 2017;54(2):123-9.

RESUMO - Contexto - A Insuficiência Hepática Aguda Grave (IHAG) é uma síndrome clínica potencialmente fatal, na qual ocorre necrose dos hepatócitos, perda da arquitetura hepática e deterioração de suas funções. Dentre as principais causas da IHAG está a hepatotoxicidade decorrente de agentes químicos, que lesam os hepatócitos e acarretam aumento das espécies reativas de oxigênio. A vitamina E tem alta atividade antioxidante biológica e é amplamente distribuída nos tecidos. Objetivo - Avaliar o efeito antioxidante da Vitamina E no modelo de IHAG. Métodos - Foram utilizados 56 ratos, com peso médio de $300 \mathrm{~g}$, divididos em oito grupos, quatro grupos avaliados em 24 horas e quatro em 48 horas após a indução: grupo controle (CO); Vitamina E (Vit.E); Tioacetamida (TAA) e Tioacetamida + Vitamina E (TAA+Vit.E). Os ratos foram submetidos a injeções de tioacetamida, na dose de $400 \mathrm{mg} / \mathrm{Kg}$ de peso i.p., no início do experimento e, posteriormente, após 8 horas. A vit E (100 mg//Kg i.p.) foi administrada 30 minutos após a segunda dose de tioacetamida. Os animais do tempo 48 horas receberam mais duas doses de vit. E (24h e $36 \mathrm{~h}$ ). Transcorridas 24 ou 48 horas após a administração da primeira dose de TAA, os animais foram pesados, anestesiados e o sangue retirado para a avaliação da integridade hepática através das enzimas Aspartatoaminotransferase (AST) e Alanina aminotransferase (ALT). O tecido hepático foi retirado para avaliação da lipoperoxidação através da técnica de TBARS, atividade das enzimas antioxidantes $\mathrm{SOD}, \mathrm{CAT}, \mathrm{GPx}$, e GST, avaliação de $\mathrm{NO}_{2} / \mathrm{NO}_{3}$ e avaliação histológica pela coloração de hematoxilina e eosina nos dois tempos. Os resultados foram expressos como média \pm erro padrão e a análise estatística utilizada foi ANOVA, seguido de teste de Student-Newman-Keuls, considerado significativo $P<0,05$. Resultados - Após o tratamento com a vit. E, observamos uma redução nas enzimas de integridade hepática AST (U/L) (101,32 $\pm 19,45$ em 24h e 97,85 $\pm 29,65$ em 48h) relacionado ao grupo TAA

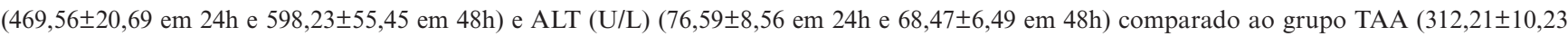
em $24 \mathrm{~h}$ e $359,15 \pm 17,58 \mathrm{em} 48 \mathrm{~h}$ ). Houve uma redução da LPO (nmol/mg Prot), no grupo TAA+Vit.E (0,77 $\pm 0,07$ em $24 \mathrm{~h}$ e $0,95 \pm 0,08$ em $48 \mathrm{~h})$ com-

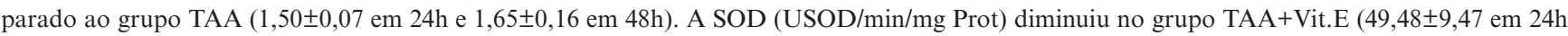
e $62,45 \pm 18,47 \mathrm{em} 48 \mathrm{~h}$ ) relacionado ao grupo TAA $(98,46 \pm 15,48 \mathrm{em} 24 \mathrm{~h}$ e $154,13 \pm 21,46 \mathrm{em} 48 \mathrm{~h}$ ), assim como a GST (nmol/min/mg Prot) no grupo

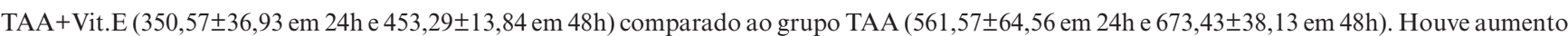

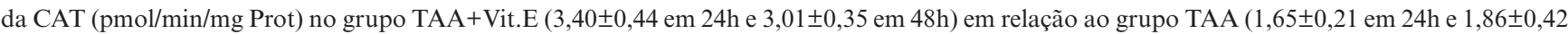
em 48h). A GPx (nmol/min/mg Prot) aumentou em 24h no grupo TAA+Vit.E $(1,01 \pm 0,16)$ comparado ao grupo TAA $(0,41 \pm 0,04)$ e diminuiu em $48 \mathrm{~h}(1,19 \pm 0,17)$ em relação ao grupo TAA $(1,76 \pm 0,21)$. Verificou-se redução nos níveis de $\mathrm{NO}_{2} / \mathrm{NO}_{3}(\mathrm{mmol} / \mathrm{L})$ no grupo TAA+Vit.E $(31,47 \pm 4,26$ em

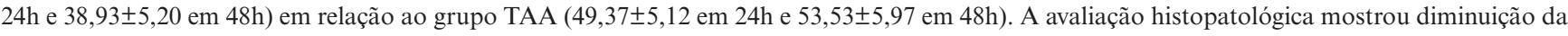
lesão hepática (necrose e inflamação) em ambas os tempos estudados. Conclusão - Estes resultados sugerem que a vitamina $\mathrm{E}$ foi capaz de proteger o fígado de lesões causadas por tioacetamida.

DESCRITORES - Falência hepática aguda. Tioacetamida. Estresse oxidativo. Antioxidantes.

\section{REFERENCES}

1. Alzoubi KH, Khabour O F, Salah H A, Hasan Z, et al. Vitamin E prevents highfat high -carbohidrates diet-induced memory impairment: The role of oxidative stress. Physiol Behav. 2013;119:72-8.

2. Bhatti FR, Mehmood A, Wajid N, Rauf M, Khan S, Riazuddin S, et al. Vitamin E protects chondrocytes against hydrogen peroxide-induced oxidative stress in vitro. Inflamm Res. 2013;62:781-9.

3. Boveris A, Chance B. The mitochondrial generation of hydrogen peroxide General properties and effect of hyperbaric oxygen. Biochem J. 1973;134:707-16

4. Buege JA, Aust SD. Microsomal lipid peroxidation. Methods Enzymol. 1978;52:302-9.

5. Chieli E, Malvadi G. Role of Cyt P-450 dependent and FAA containing mono oxygenases in the bioactivation of thioacetamide, thiobezamide and their sulophoxides. Biochem Pharmacol. 1985; 34:395-1.

6. Chu CJ, Hsiao CC, Wang TF, Chan CY, Lee FY, Chang FY, et al. Prostacyclin inhibition by indomethacin aggravates hepatic damage and encephalopathy in rats with thioacetamide-induced fulminant hepatic failure. World J Gastroenterol. 2005;11:232-6.
7. David C, Rodrigues G, Bona S, Meurer L, González-Gallego J, Tuñón M, et al. Role of quercetin in preventing thioacetamide-induced liver injury in rats. Toxicol Pathol. 2011;39:949-57.

8. De Oliveira CR, Ceolin J, De Oliveira RR, Schemitt EG, Colares JR, Bauermann $\mathrm{LF}$, et al. Effects of quercetin on polychlorinated biphenyls-induced liver injury in rats. Nutr Hosp. 2014; 1141-8.

9. Diesen DL, Kuo PC. Nitric oxide and redox regulation in the liver: Part I. General considerations and redox biology in hepatitis. J Surg Res. 2010;162:95-109.

10. Diez-Fernandez C, Sanz N, Cascales M. Changes in glucose-6-phosphate dehydrogenase and malic enzyme gene expression in acute hepatic injury induced by thioacetamide. Biochem Pharmacol. 1996;51:1159-63.

11. Fedstein AE. Novel insights into the pathophysiology of nonalcoholic fatty liver disease. Semin Liver Dis. 2010;30:391-401.

12. Fitzhugh OG, Nelson AA. Liver tumours in rats fed thiourea or thioacetamide Science, 1948; 108: 626-28.

13. Flohé L, Gunzler WA. Assays of glutathione peroxidase. Methods Enzymol 1984;105:114-21. 
14. Fontana L, Moreira E, Torres MI, Fernández MI, Ríos A, De Medina FS, et al. Serum amino acid changes in rats with thioacetamide-induced liver cirrhosis. Toxicology. 1996;106:197-206.

15. Halliwell B, Gutteridge J. Free Radicals in Biology and Medicine. 4th edn. New York: Oxford University Press Inc; 2007.

16. Herrera E, Barbas C. Vitamin E: action, metabolism and perspectives. J Physiol Biochem. 2001; 57:43-56.

17. Jeon YH. Vitamin E, an antioxidant, as a possible therapeutic agent for treating pain. Korean J Pain. 2013;3:314-5.

18. Lee, WM. Acute liver failure in the United States. Semin. Liver Dis. 2003;23:217-26.

19. Llesuy SF, Milei J, Molina H, Boveris A, Milei S. Comparison of lipid peroxidation and myocardial damage induced by adriamycin and 4'- epiadriamycin in mice. Tumori. 1985,71:241-9.

20. Mangipudy RS, Chanda S, Mehendale HM. Tissue repair response as a function of dose in thioacetamide hepatotoxicity. Environ Health Perspect. 1995;103:260-7.

21. Mannervick BGC, Guthenberg C. Glutationa Transferase (human placenta). Methods Enzymol. 1981;77:231-5.

22. Marques C, Licks F, Zattoni I, Borges B, De Souza LER, Marroni, CA, et al. Antioxidant properties of glutamine and its role in VEGF-Akt pathways in portal hypertension gastropathy. World J Gastroenterol. 2013;19:4464-74.

23. Marques C, Mauriz JL, Simonetto D, Marroni CA, Tuñon MJ, González-Gallego J, Marrón NP. Glutamine Prevents gastric oxidative stress in an animal model of portal hypertension gastropathy. Ann Hepatol. 2011;4:531-39.
24. Mattos AA, Dantas-Corrêa EB. Tratado de Hepatologia. 4 Ed. Rubio: São Paulo, 2010. 1.024 p.

25. Misra HP, Fridovich I. The role of superoxide anion in the autoxidation of epinephrine and a simple assay for superoxide dismutase. J Biol Chem. 1972;247:3170-5

26. Morgan-Martins MI. Estresse Oxidativo e Antioxidantes. In Marroni, NP. Radicais Livres no processo saúde-doença: da bancada à clínica/ Norma Possa Marroni, Maria Isabel Morgan-Martins, Marilene Porawski (organizadoras) Curitiba, PR: CRV, 2012

27. Muñoz RS, Maroja JL, Vasconcelos FR, Melo J. Avaliação cognitiva breve para detecção de encefalopatia em pacientes com doença hepática crônica. GE Port J Gastroenterol. 2013;20:255-60.

28. Mustafa HN, Awdan AS, Hegazy GA. Protective role of antioxidants on thioacetamide-induced acute hepatic encephalopathy: Biochemical and Ultrastructural study. Tissue and Cell. 2013;45:350-62.

29. Neal RA. Halpert, J. Toxicology of thionosulfer compounds. Annu Rev Pharmacol Toxicol. 1982;22:321-9.

30. Niki E. Role of vitamin $\mathrm{E}$ as a lipid-soluble peroxil radical scavenger: in vitro and in vivo edidence. Free Radical Biol Med. 2014;66:3-12.

31. Schemitt EG, Colares JR, Hartmann RM, Morgan-Martins MI, Marroni CA, Tuñón MJ, Marroni NP. Effect of glutamine on oxidative stress and inflammation in a rat model of fulminant hepatic failure. Nutr Hosp. 2016;33:92. 